\title{
Verzekeringsgeneeskundige witdaging Adequate beoordeling van long covid
}

Moniek van Zitteren, Marit van Boreen, Jerry Spanjer

\begin{abstract}
Inmiddels is bekend dat covid-19 kan leiden tot langdurige klachten met forse beperkingen. Deze zijn niet altijd makkelijk te objectiveren of feitelijke informatie ontbreekt. Ontwikkeling van een leidraad van moeilijk objectiveerbare klachten voor de bedrijfsgeneeskundige en verzekeringsgeneeskundige praktijk is wenselijk om zo tot een adequate beoordeling van de belastbaarheid van long-covidpatiënten te komen.
\end{abstract}

Dr. Moniek van Zitteren is klinisch epidemioloog en aios verzekeringsgeneeskunde bij $U W V$, Eindhoven moniek.vanzitteren@uwv.nl Drs. Marit C. van Boreen was tot eind 2020 internist bij het Sint Jans Gasthuis in Weert, thans werkzaam als aios verzekeringsgeneeskunde bij UWV Eindhoven

Dr. Jerry Spanjer is verzekeringsarts bij UWV Assen, onderzoeker en docent

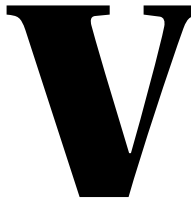
oorlopig zal men terug moeten vallen op bekende informatie van gelijksoortige medische aandoeningen en de nu geldende protocollen. Samenwerking tussen bedrijfsgeneeskunde en verzekeringsgeneeskunde lijkt hierin essentieel, evenals het bereiken van consensus in de beoordeling van dergelijke klachten.

\section{Nieuwe aandoening}

Ruim een jaar geleden werden onze collegae in de curatieve sector en bedrijfsartsen geconfronteerd met de eerste covid-19-patiënten. Het betrof een nieuwe aandoening, met potentieel ernstige gevolgen, waarover op dat moment weinig kennis beschikbaar was. Daarom moest men in de kliniek varen op de aanwezige informatie van dat moment. Deze kennis kwam voornamelijk voort vanuit gelijksoortige ziektebeelden. Inmiddels heeft men de nodige ervaring opgedaan waardoor covid-19-patiënten beter behandeld kunnen worden. Desondanks bestaan er nog altijd kennishiaten en is het vergaren van wetenschappelijke kennis in volle gang. Verzekeringsartsen zullen in beginsel weinig geconfronteerd worden met de acuut zieke covid-19-patiënt. Tot heden zijn ruim 1 miljoen personen tussen de 20 en 64 jaar positief getest op covid-19 vanuit de GGD. ${ }^{1} \mathrm{Nu}$ de eerste golven van de pandemie achter de rug zijn wordt duidelijk dat covid-19 ook kan leiden tot blijvende klachten, lang ( $>3$ maanden) nadat de acute infectie is doorgemaakt (long covid).,3 Naar schatting is dit ongeveer 10 procent van de besmette personen. ${ }^{2}$ Dit betreft een relatief jonge populatie van mensen in de werkende leeftijd (20-50 jaar) die langdurig uitvallen. ${ }^{4}$ 
Er is echter nog niets bekend over de gevolgen op de lange termijn en wat dit betekent voor de belastbaarheid van long-covidpatiënten.

\section{Orgaan-specifieke klachten}

De klachtenpresentatie van long covid loopt erg uiteen. Dit scala varieert van symptomatische restklachten waarbij covid-19 direct heeft geleid tot respiratoire, cardiovasculaire en neurologische complicaties of indirecte complicaties ten gevolge van bijvoorbeeld secundaire hypoxie of trombose ${ }^{3}$, tot vermoeidheidsklachten. ${ }^{3-5}$ Zo komen bij long covid vaak orgaan-specifieke klachten voor waarbij vaak geen aantoonbare schade kan worden vastgesteld. ${ }^{5}$ Eerder werd in dit tijdschrift ingezoomd op de vergelijking tussen long covid en het chronischevermoeidheidssyndroom. ${ }^{5}$ Ondanks schattingen ontbreken duidelijke prevalentiecijfers op dit moment met betrekking tot langdurige klachten, zoals bijvoorbeeld chronische vermoeidheid.

De variatie in klachten en huidige kennishiaten in combinatie met de impact op het dagelijks leven rondom long covid, maakt dat de verzekeringsarts voor een uitdaging kan komen te staan in de sociaal-medische beoordeling.

De eerste sociaal-medische beoordelingen in het kader van de Ziektewet (onder meer Eerstejaars Ziektewetbeoordeling) dienen zich nu aan en zullen gevolgd worden door de WIA-beoordelingen. Welke houvast heeft de verzekeringsarts in de sociaal-medische beoordeling om bij dit nieuwe ziektebeeld (long covid) tot een objectief oordeel te komen?

\section{Ervaringen met Q-koorts}

Ruim tien jaar geleden vond in het zuidoostelijk deel van Nederland een uitbraak plaats van Q-koorts. ${ }^{6}$ Covid-19 kan, net als Q-koorts, leiden tot moeilijk objectiveerbare klachten, zoals bij het Q-koortsvermoeidheidssyndroom. ${ }^{4,6} \mathrm{Er}$ is een grote groep patiënten die dagelijks nog altijd beperkingen ervaart ten gevolge van deze ziekte. ${ }^{4}$ Ook voor Q-koorts ontbraken destijds adequate richtlijnen waarop men zich kon baseren. Kennis daaromtrent was hard nodig. Daarom werd Q-support opgericht, een expertisecentrum voor Q-koorts waarop zowel patiënten als zorgprofessionals een beroep kunnen doen. ${ }^{4}$ De inzet van dit centrum is nog altijd actueel.

\section{Aandachtspunten}

Long covid kan leiden tot langdurige klachten met forse beperkingen. De klachtenpresentatie loopt erg uiteen en moeilijk objectiveerbare klachten kunnen hier een onderdeel van zijn.

- Er bestaat nog geen eenduidig wetenschappelijk kader voor de beoordeling van de belastbaarheid bij long covid.

> Interdoktervariatie dient vermeden te worden om onwenselijke verschillen in de uiteindelijke beoordeling te voorkomen.

$>$ Ontwikkeling van een algemene richtlijn die zich richt op beoordeling van belastbaarheid bij moeilijk objectiveerbare klachten is wenselijk.

$>$ Samenwerking tussen bedrijfs- en verzekeringsartsen lijkt hierin voor de hand liggend.

In de verzekeringsgeneeskundige praktijk wordt vaak gewerkt met de kennis uit de richtlijnen van het chronischevermoeidheidssyndroom en de 'medische' Q-koortsrichtlijn.

Vanwege de parallellen die te trekken zijn tussen Q-koorts en long covid is in een vroeg stadium initiatief genomen om C-support op te richten. ${ }^{4}$ Uit een eerste analyse van C-support blijkt dat veel patiënten problemen ervaren door langdurige klachten na het doormaken van de acute infectie. ${ }^{4}$ In deze analyse gaat het om patiënten die actief zijn aangemeld bij C-support. Daardoor is er mogelijk wel sprake van selectiebias. Naast de gezondheidsproblemen ervaren veel patiënten ook problemen op het gebied van werk en financiën. Dit komt overeen met wat eerder gezien werd na de Q-koorts-epidemie waarbij ook de sociaal-medische beoordeling uitdagingen kent. Het is daarom wenselijk dat ook verzekeringsartsen zich voorbereiden op de stroom aan patiënten die een beroep zullen gaan doen op de socialeverzekeringswetten.

\section{Long-covidklantgroepen}

In de verzekeringsgeneeskundige praktijk zullen waarschijnlijk grofweg twee groepen te onderscheiden zijn. Enerzijds is er de groep long-covidpatiënten die een ziekenhuisopname heeft doorgemaakt - al dan niet met opname op de intensive care (IC). Van deze patiëntengroep is (uitgebreide) medische informatie van de 


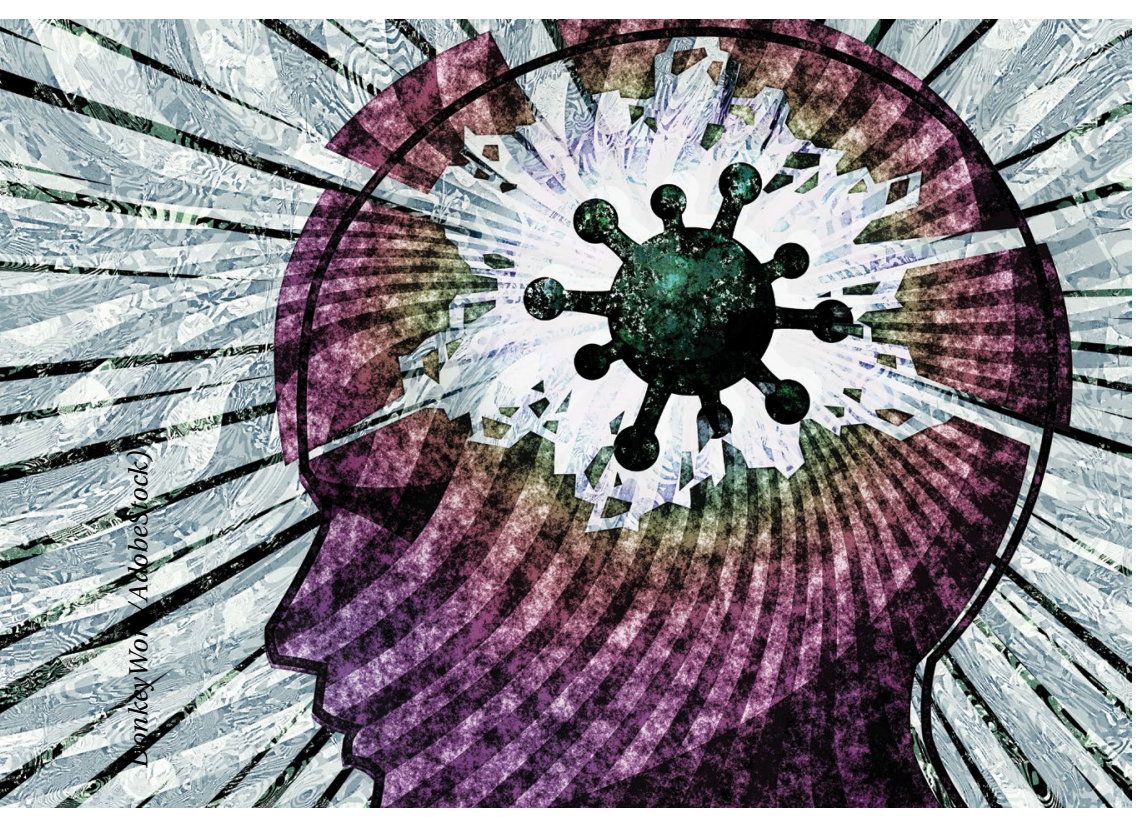

Een duidelijke richtlijn zou de omvang van interdoktervariatie kunnen verkleinen

behandelaars beschikbaar. Daarnaast dient men alert te zijn op het voorkomen van het Post Intensive Care Syndroom (PICS). Het PICS kenmerkt zich door een breed scala aan fysieke, cognitieve en psychische klachten. ${ }^{7}$ Het is waarschijnlijk dat de covid-19-groep die een IC-opname achter de rug heeft ook klachten zal rapporteren van PICS. ${ }^{7}$

Gezien de grote diversiteit en overlap aan klachten is het in de praktijk waarschijnlijk lastig om PICS goed te onderscheiden van long covid. Op dit moment bestaat er nog geen uniforme classificatie voor het duiden van de ernst van long-covidklachten. Wel kan de medische informatie uit de curatieve sector, naast de klachtenpresentatie van de patiënt, houvast bieden in de sociaal- medische beoordeling. Anderzijds zullen verzekeringsartsen te maken krijgen met patiënten die geen ziekenhuisopname hebben gehad, maar die wel restklachten ervaren. Deze patiënten zijn vaak enkel positief getest middels een sneltest of PCR in de teststraat. Aanvullende diagnostiek is vaak niet voor handen.

Ook bestaat er een aanzienlijke groep die nog altijd klachten ervaart, maar die tijdens de eerste golf niet getest is wegens het ontbreken van testcapaciteit (56\%). ${ }^{4}$ Aanvullende behandeling in de vorm van bijvoorbeeld revalidatie heeft vaak ook niet plaatsgevonden. Voor deze laatste categorie patiënten ontbreekt dus vaak de feitelijke informatie in het kader van arbeidsongeschiktheid ten gevolge van ziekte/gebrek. Voor de verzekeringsarts zal dit een uitdagende groep vormen om tot een objectieve beoordeling te komen.

\section{Sociaal-medische beoordeling en interdoktervariatie}

Voor elke sociaal-medische beoordeling geldt dat verzekeringsartsen zich moeten wenden tot de geldende wetgeving en beschikbare richtlijnen. Dit zal voor elke aandoening altijd het uitgangspunt blijven. Zo ook voor long covid. Uit focusgroeponderzoek naar patiënten met fibromyalgie (SOLK) blijkt echter dat er sprake kan zijn van zogenoemde 'interdoktervariatie', vooral bij moeilijk objectiveerbare klachten. ${ }^{8}$ De grootste variatie wordt gezien in het wel of niet aannemen van een urenbeperking en de omvang daarvan. ${ }^{8}$ Mogelijk kan een duidelijke richtlijn de omvang van interdoktervariatie verkleinen. Uit de huidige kennis over long covid komt naar voren dat chronische vermoeidheidsklachten voor een belangrijk deel bijdragen aan de klachtenpresentatie. Daarmee is het voorstelbaar dat patiënten een urenbeperking zullen claimen. Er bestaat nog geen uitgekristalliseerd wetenschappelijk kader voor de beoordeling van long covid, zeker wanneer zij zich presenteren met moeilijk objectiveerbare klachten. Daarom lijkt er een aanzienlijk risico te bestaan op interdoktervariatie, los van een geclaimde urenbeperking. Interdoktervariatie kan leiden tot onwenselijke verschillen in de uiteindelijke beoordeling en ongewenste consequenties voor het toekennen van uitkeringen. ${ }^{8}$ 


\section{Long covid anno nu}

Verzekeringsartsen zullen in dit stadium van de pandemie net als collegae uit de curatieve sector en bedrijfsartsen terug moeten vallen op hetgeen wel bekend is. Zoals eerder aangegeven dient de uitvoerende basis van de sociaal-medische beoordeling niet anders te zijn: er moet immers altijd zorgvuldig en objectief gekeken worden naar de patiënt als geheel, zoals de medische voorgeschiedenis, het premorbide functioneren, klachtenpresentatie, het ziektebeloop en gevolgde behandelingen. Factoren zoals coping en lijdensdruk worden daar door de verzekeringsarts in meegenomen alsook de medisch beschikbare informatie van derden. Ervaren belemmeringen zullen daaruit worden gedestilleerd om deze op basis van het ICF-model te vertalen naar beperkingen. Uitgangspunt vormen het Schattingsbesluit en Medisch Arbeidsongeschiktheidscriterium (MAOC) waarbij wordt gekeken naar de consistentie tussen stoornis, beperkingen en handicap (ICF-model). De sterkste argumenten komen (bij moeilijk objectiveerbare aandoeningen) namelijk voort uit de samenhang tussen consistentie, plausibiliteit en ziekte/gebrek. ${ }^{8}$ Zo lang er geen verzekeringsgeneeskundige richtlijnen voor moeilijk objectiveerbare klachten, zoals long covid, voor handen zijn kan bestaande ervaring en evidence gebruikt worden als houvast. Daarnaast kan gedacht worden aan het opstellen van zogenoemde 'ankercasuïstiek', specifieke casuïstiek besprekingen, of het uitvoeren van een oordeel door meerdere artsen om zo tot een gemiddelde beoordeling te komen bij twijfelgevallen. ${ }^{8} \mathrm{De}$ sociaal-medische beoordeling voor long covid zal daarom een dynamisch proces gaan vormen waarbij opgevulde kennishiaten aanleiding kunnen zijn voor het bijstellen van de huidige visie, of zelfs eerdere beoordelingen.

\section{Toekomstperspectief}

Op basis van eerdere ervaringen in het verleden met dergelijke ziektebeelden lijkt een 'call to action' op zijn plaats. Uit de Q-koortsepidemie is naar voren gekomen dat een substantieel deel van de patiënten op de lange termijn klachten ervaart die gevolgen hebben voor hun dagelijkse functioneren én het participeren in de maatschappij. Gezien de parallellen met long covid is er in dat kader vrijwel direct actie ondernomen door bijvoorbeeld het opzetten van C-support en wetenschappelijk onderzoek (onder meer in de kliniek). Ook vanuit de verzekeringsgeneeskunde is het nodig om te anticiperen op actuele ontwikkelingen.

\section{Ontwikkeling van kennis en richtlijnen}

Het gebrek aan adequate richtlijnen stelt bedrijfsen verzekeringsartsen voor een uitdaging om houvast te krijgen bij de beoordeling van belastbaarheid en vooral een urenbeperking. Daarom is het noodzakelijk om een praktische leidraad te ontwikkelen. Recent is door de NVAB een leidraad opgesteld over herstel en re-integratie na covid en de post-acute gevolgen. ${ }^{2}$ Deze leidraad richt zich niet specifiek op het beoordelen van belastbaarheid. Wel wordt gerefereerd aan het ICF-model. ${ }^{2}$ Door het beperkte aantal (heterogene) studies is er weinig evidence in hoe om te gaan met het opstellen van belastbaarheid bij moeilijk objectiveerbare klachten. Long covid is niet het eerste en zal vast niet het laatste ziektebeeld zijn wat zich presenteert met moeilijk objectiveerbare klachten. Daarom is het wenselijk om een algemene richtlijn te ontwikkelen die houvast biedt voor dergelijke ziektebeelden. Voor nu én met oog op de toekomst. Naast long covid valt te denken aan bijvoorbeeld: chronischevermoeidheidssyndroom, whiplash, fibromyalgie, Q-koorts, lyme en moeheid na kanker. Het is belangrijk dat professionele beoordelaars hierin een prominente rol spelen waarbij niet enkel diagnosegericht of vanuit curatieve behandelmogelijkheden gedacht wordt. In het verlengde daarvan is het opzetten van wetenschappelijk onderzoek gericht op de beoordeling en belastbaarheid van de long-covidpatiënt wel belangrijk. Op deze manier kan ziekte-specifieke informatie wel opgenomen worden in een algemene richtlijn voor moeilijk objectiveerbare klachten. Evidencebased informatie kan op de langere termijn dan vertaald worden naar zogenaamde evidencebased practice in de spreekkamer. Dit is nodig om tot een adequaat sociaal-medisch oordeel te komen en om het risico op potentiële interdoktervariatie te verkleinen. Daarnaast is het belangrijk te realiseren dat verzekeringsartsen er niet 'alleen' voor staan. Zo kan men altijd advies inwinnen bij het 


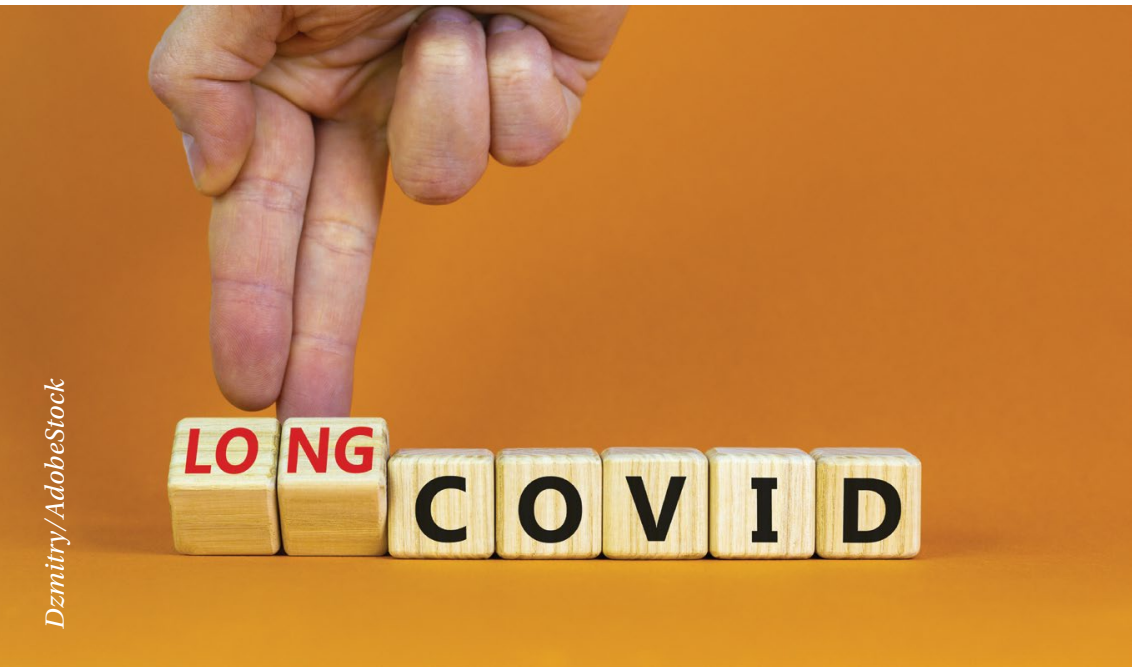

expertisecentrum van C-support, maar ook het organiseren van specifieke casuïstiekbesprekingen - al dan niet onderling - en het vergaren van 'ankercasuïstiek' kunnen hierbij behulpzaam zijn.

\section{Bedrijfsarts en verzekeringsarts: samen staan we sterker}

In het kader van long covid is varen op bestaande kennis nodig. Daarbij is het belangrijk dat men zich realiseert dat niet alleen de curatieve sector, maar ook de bedrijfsartsen al geruime tijd ervaring hebben opgedaan met de begeleiding van covidpatiënten. Bedrijfsartsen hebben in de eerste periode al te maken gehad met de acute covid-19-patiënt, maar ook zij worden nu geconfronteerd met de begeleiding van longcovidpatiënten. Bij het opstellen van belastbaarheid is het voorstelbaar dat bedrijfsartsen tegen dezelfde uitdagingen aanlopen als verzekeringsartsen. Er zal ongetwijfeld ook interdoktervariatie bestaan tussen bedrijfsartsen onderling alsook tussen bedrijfsartsen en verzekeringsartsen bij het opstellen van belastbaarheid. Daarom lijkt het wenselijk dat bedrijfsartsen en verzekeringsartsen vaker met elkaar in gesprek gaan, bijvoorbeeld over de long-covidpatiënt. Op deze manier kunnen ervaringen worden uitgewisseld en kunnen wellicht de handen ineen geslagen worden om tot een gezamenlijke richtlijn of leidraad te komen voor beoordeling van belastbaarheid bij moeilijk objectiveerbare klachten. Ontwikkeling van een dergelijke leidraad kan bijdragen aan de kwaliteit van een objectieve beoordeling, het verminderen van interdoktervariatie, en - zeker niet onbelangrijk - het verminderen van ongewenste consequenties voor het toekennen van uitkeringen.

\section{Conclusie}

De (grote) toestroom aan sociaal-medische beoordelingen van long-covidpatiënten komt nu op gang. Verzekeringsartsen moeten hiervoor vooralsnog terugvallen op bestaande wet- en regelgeving, de actuele kennis en evidence en hun praktijkervaring. Het opbouwen van een wetenschappelijke basis is nodig. Ontwikkeling van een algemene richtlijn voor beoordeling van belastbaarheid bij moeilijk objectiveerbare klachten kan hiervoor behulpzaam zijn.

Een gezamenlijk initiatief met de bedrijfsgeneeskunde lijkt hierin voor de hand liggend.

\section{Referenties}

1. RIVM-rapportage (laatst geraadpleegd d.d. 05-05-2021): rivm.nl/sites/default/files/ 2021-04/COVID-19_WebSite_rapport_ wekelijks_20210427_1126_final.pdf

2. NVAB-leidraad Herstel en re-integratie in het kielzog van COVID-19; Post-acute gevolgen van SARS CoV-2 infectie (PASC). Versie 1, 10 mei 2021.

3. Wade D. Rehabilitation after COVID-19: an evidence-based approach.

Clinical Medicine 2020; 20(4):359-364.

4. Dossier C-Support. Eerste indrukken COVID-19 patiënten met langdurige klachten. Maart 2021.

5. Van Dijk F. Helpt long covid chronisch vermoeidheidssyndroom te doorgronden? Ofomgekeerd? Tijdschr Bedr Verzekeringsgeneeskd 2021; 29(1):26-30.

6. Delsing C, Kullberg B, Bleeker-Rovers C. Qfever in the Netherlands from 2007 to 2010. Neth J Med. 2010;68(12):382-7.

7. Wolters A, Schuckman M. Impact van een IC-behandeling: Post Intensive Care Syndroom. Tijdschr Bedr Verzekeringsgeneeskd 2021; 29(1):6-9.

8. Spanjer J. Urenbeperking bij SOLK: welke argumenten gebruiken verzekeringsartsen? Tijdschr Bedr Verzekeringsgeneeskd 2016; 24(5):200-205. 